\title{
The first report of terrestrial Petroxestes from the Lower Cretaceous Yixian Formation, western Liaoning, China
}

\author{
Jiang Xu, En-Pu Gong ${ }^{*}$, Tie-Hui Wang and Xiao-Hong Chen
}

\begin{abstract}
Abundant aggregated, elongate, shallow borings have been discovered from the Lower Cretaceous Yixian Formation in western Liaoning, China. By contrast with several similarly-shaped trace fossils, such as Asthenopodichnium, Teredolites, Rogerella, Cubiculum and Petroxestes, their appearance, size, arranged modes, distribution density and substrate types are most similar with traces of Petroxestes that was discovered from Southern Ohio, USA (J. Paleontol. 62: 306-08, 1988). This is the first report of Petroxestes from China, and also the first report of these traces from a terrestrial environment.
\end{abstract}

Keywords: Trace fossils, Jehol biota, Carbonate rocks, Terrestrial Petroxestes

\section{Introduction}

A large number of well-preserved Jehol Biota fossils have been discovered in the Lower Cretaceous deposits in western Liaoning, China, consisting of macroplants, palynomorphs, charophytes, protistans, conchostracans, ostracods, shrimps, insects, bivalves, gastropods, fish, turtles, lizards, pterosaurs, crocodiles, dinosaurs, birds, and mammals (Sha 2007; Pan et al. 2012; Pan et al. 2013; Ding et al. 2016). However, reported trace fossils are relatively scarce (Xing et al. 2009). Nevertheless, trace fossils are irreplaceable evidences for some palaeontological behavior studying, for example, burrowing. Nowadays, ichnology not only has important applications in classical palaeobiology, but also is of great value in the more applied disciplines of palaeoenvironmental and stratigraphical analysis (Mcllroy 2004).

Petroxestes pera is an ichnospecies erected by Wilson and Palmer (1988) from the Ordovician of Ohio (USA), and interpreted to have been produced by boring bivalves. It is a bioerosional ichnotaxon, occurring within lithic substrates, and is characterized by a shallow to deep elongate outline, broadly parallel sides, and a rounded bottom in longitudinal and transverse section (Pickerill et al. 2001). It is densely distributed on the surface of carbonate rocks from the Lower Cretaceous

\footnotetext{
* Correspondence: gongep@mail.neu.edu.cn

Resources and Civil Engineering College of Northeastern University, Shenyang 110819, Liaoning Province, China
}

Yixian Formation in western Liaoning, China. This paper aims to give a detailed description of the morphology of these trace fossils and point out their differences with other similarly-shaped traces.

\section{Geological setting}

Since the Early Cretaceous, the stress state in northeastern China changed from tension to extension (Zhu et al. 2008), resulting in the formation of several Mesozoic basins (Jiang et al. 2007; Huang 2015; Zhang et al. 2016). Jin-Yang Basin and Yixian Basin are two of these basins in western Liaoning (Fig. 1), and are characterized by producing numerous Jehol Biota fossils (e.g. Hou et al. 1995; Ji and Ji 1996, 1997; Hu et al. 1997; Chen et al. 1998; Sun et al. 1998; Ji et al. 1998; Chang et al. 2003; Ding et al. 2003; Ji 2004). In both basins, fossils were mainly discovered from the Yixian Formation. However, the sedimentary characteristics of the Yixian Formation in these two basins are different. Firstly, in Yixian Basin, Yixian Formation is comprised of many discontinuous members that are cut off by igneous rocks (e.g. Laogonggou, Yenangou, Zhuanchengzi, Dakangpu and Jingangshan Members), each of which has limited thickness. However, in the Jin-Yang Basin, the Yixian Formation is relatively continuous with a great thickness of about 135 m (Wang et al. 1998, 2004). Secondly, lithologically, in the Jin-Yang Basin, except for one carbonate rock stratum and several limestone lenses, the Yixian 


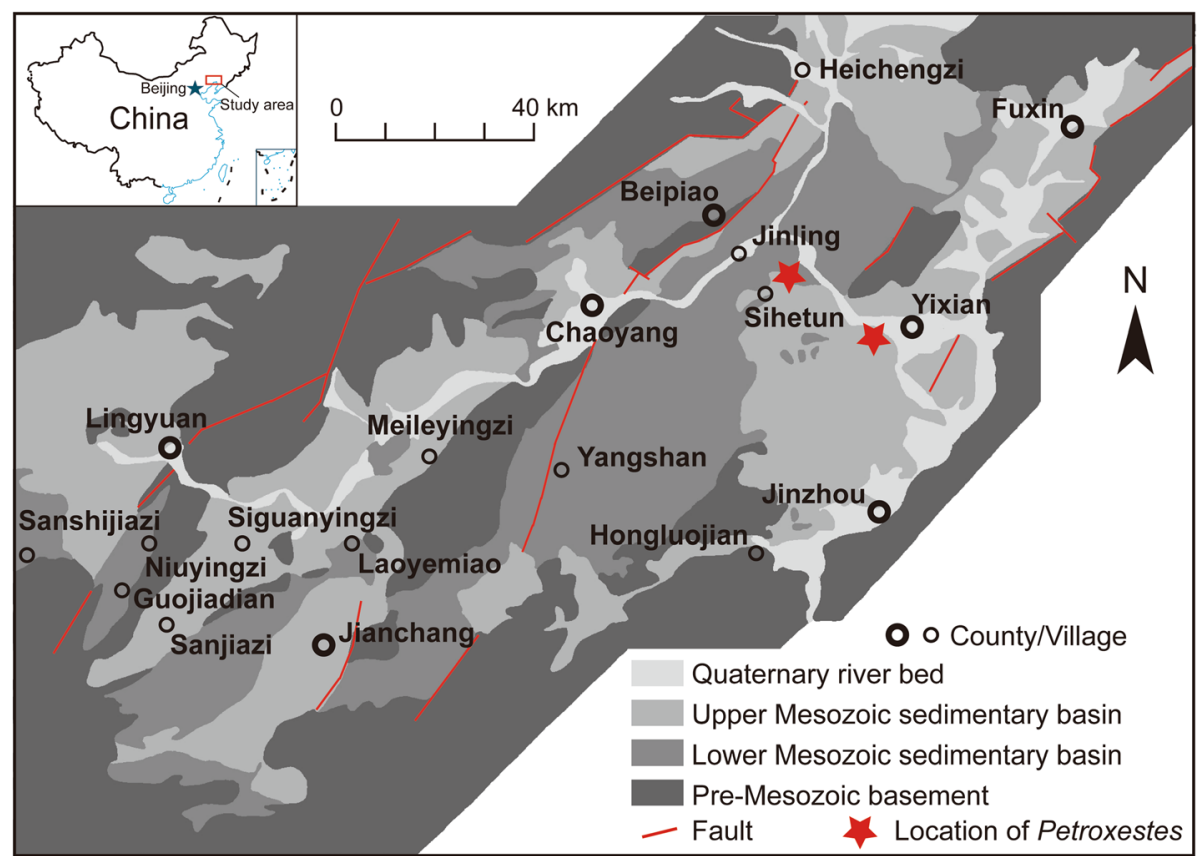

Fig. 1 Distribution of Mesozoic basins and distribution of Petroxestes in western Liaoning, NE China (modified from Gong et al. 2017). The insert map is modified after the State Bureau of Surveying and Mapping, China (No. GS(2016)1603)

Formation is mainly composed of sedimentary tuff, tuffaceous mudstone and tuffaceous shales, where fossils were mainly preserved (Guo et al. 2001; Jiang and Sha 2007; Wang et al. 1998). Nevertheless, there are many carbonate strata occurring in the Yixian Basin (Wang et al. 2004; Zhang et al. 2006), which are generally formed under hot and arid palaeoclimates (Chen et al. 2009, 2010, 2011; Gong et al. 2007, 2011).

Petroxestes fossils have been found from two sites (Fig. 1). One (GPS coordinates $41^{\circ} 36^{\prime} 15.7^{\prime \prime} \mathrm{N} / 120^{\circ} 51^{\prime}$ $44.8^{\prime \prime} \mathrm{E}$ ) is located $4.8 \mathrm{~km}$ northeast of Sihetun village (Fig. 1), and trace fossils were discovered in the lowermost portion of the Yixian Formation. The other (GPS coordinates $41^{\circ} 32^{\prime} 37.8^{\prime \prime} \mathrm{N} / 120^{\circ} 7^{\prime} 41.8^{\prime \prime} \mathrm{E}$ ) is located $9 \mathrm{~km}$ west of Yixian county, and trace fossils were preserved in the middle portion of the Yixian Formation. The former one belongs to the Jin-Yang Basin, and the latter one belongs to Yixian Basin. All Petroxestes were discovered in situ, on the surface of carbonate rocks from the Yixian Formation.

\section{Materials and methods}

Petroxestes from these two sites are vertical shallow borings with similar morphology (Fig. 2). In plan view, they are elongate with straight or slightly-curved parallel sides and rounded ends. They show no preferred orientation. These borings have a round bottom in both longitudinal and transversal sections (Fig. 3c, d). Except for a very few traces, most are close to each other. No intersecting structures have been observed. These traces have a high density, up to 50 counts per square meter. There are no bioglyphs distributed on the inside surface of these traces. The producers were not preserved inside the traces.

There is a slight difference in the size of Petroxestes between the two areas. Petroxestes from the Jin-Yang Basin is $9-21 \mathrm{~mm}$ long and $1-3 \mathrm{~mm}$ wide. The proportion of $12-14-\mathrm{mm}$-long traces is more than $50 \%$, and 10-18-mm-long ones are exceeding 90\%. More than 56\% of traces are $2 \mathrm{~mm}$ wide. In the Yixian Basin, the length and width of Petroxestes are 11-20 $\mathrm{mm}$ and 2-4 $\mathrm{mm}$, respectively. The proportion of $14-15-\mathrm{mm}$-long traces is more than $50 \%$, and $11-15 \mathrm{~mm}$ long ones more than $80 \%$. About $42 \%$ of traces are $2 \mathrm{~mm}$ wide. However, in the two areas, the depth of traces is similar, both varying from $1.5 \mathrm{~mm}$ to $3 \mathrm{~mm}$. Generally, the width/length ratio of these Petroxestes is less than 0.2.

The main bases for the identification of these traces as borings rather than burrows are as follows. Firstly, borings are produced by physical and/or chemical erosion (usually acidic substances formed by organisms), so they usually have relatively-smooth inside surfaces (McIlroy 2004). Traces from the Yixian Formation have such surfaces (Fig. 2b-e; Fig. 3b, c). Secondly, these traces are straight in outline (Fig. 2a, b, d-e; Fig. 3b), which means they have no obvious extrusion deformation occurred during the process of diagenesis. If these traces were burrows that formed in soft sediments, it is 

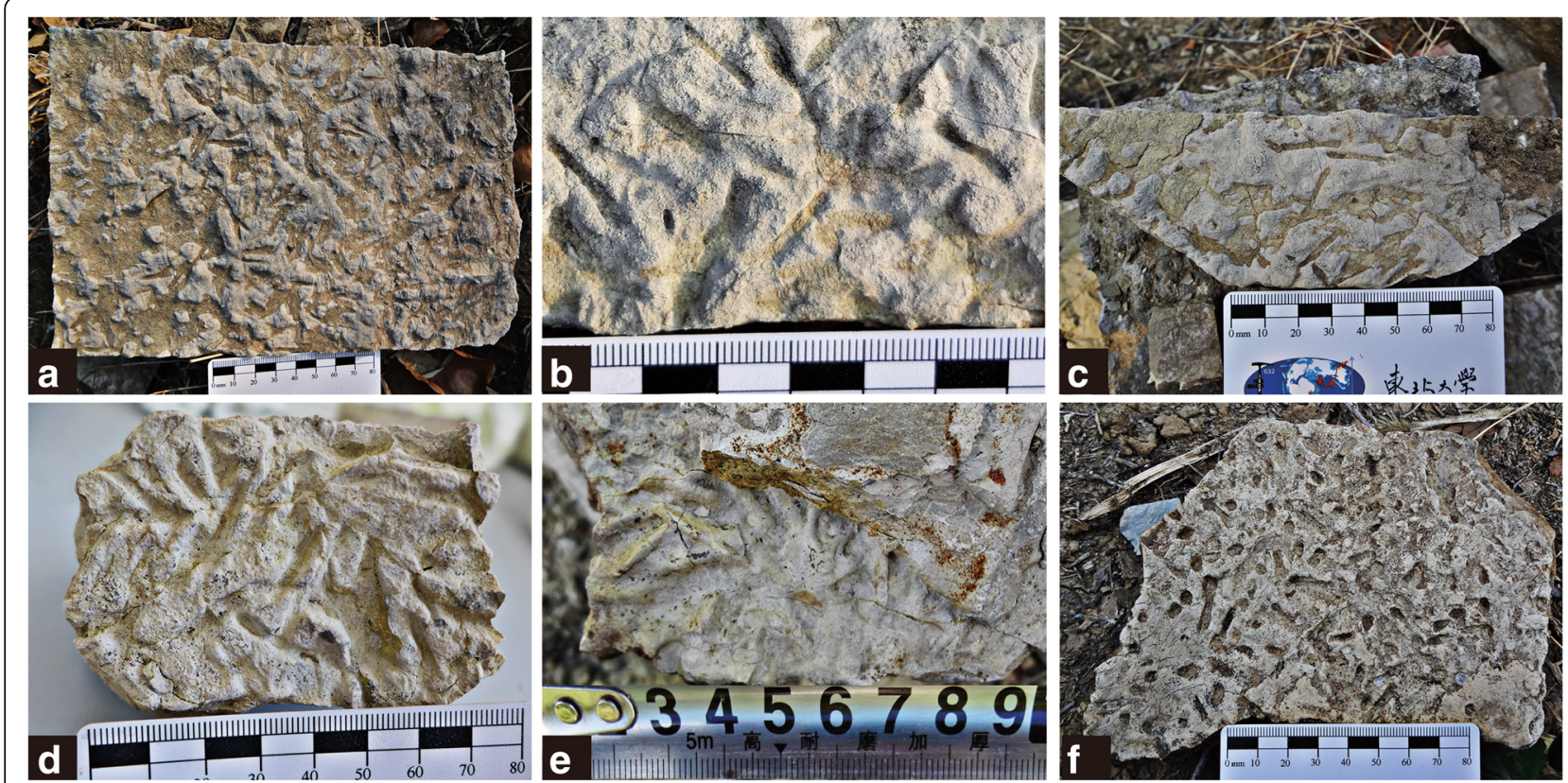

Fig. 2 Petroxestes (the elongate borings) from the Lower Cretaceous Yixian Formation, western Liaoning, China. a-c Aggregated traces of Petroxestes discovered from the Jin-Yang Basin; $\mathbf{d}-\mathbf{f}$ Petroxestes from the Yixian Basin; in e fossil casts are shown, and in $\mathbf{f}$ some Petroxestes are preserved together with Trypanites (the rounded borings)

very difficult to achieve (Miller 2007). Thirdly, these traces were preserved on surface of carbonate rocks. In a continental environment, these strata generally indicate discontinuity of sedimentation by recurrent exposure to the air and were hard when they were formed (Barrell 1917). Lastly, the following lithostratigraphic characteristics of these traces-bearing carbonate rock strata also support the identification of borings. In the
Jin-Yang Basin, carbonate stratum that bear traces is distributed in a limited area (the northeast-southwest span is about $200 \mathrm{~m}$ ). The interface between the carbonate stratum and the overlying yellowish-green siltstone is clear and there are no sand grains squeezed into the carbonate rocks (Fig. 2c). It can be inferred that before the siltstone was deposited the carbonate sediments had been consolidated. In the Yixian Basin,

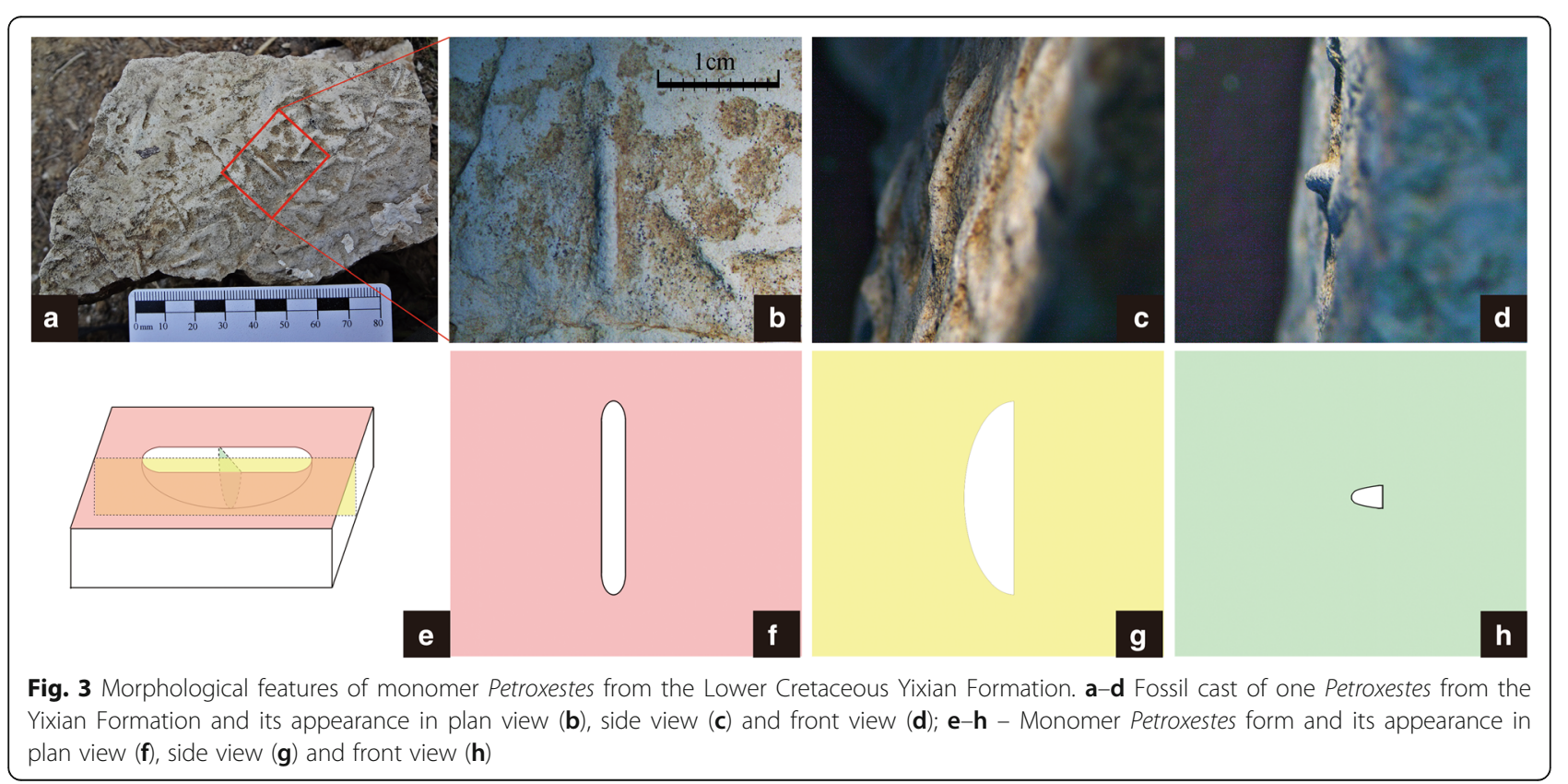


carbonate stratum that contains traces is distributed in a smaller area (the northwest-southeast span is no more than $20 \mathrm{~m}$ ). The carbonate rock, as well as other mudstone and shale, are all covered by a clastic marlstone that contains debris of sandstone, bivalve shells, three-dimensionally preserved caddisfly larval cases and so on (Gong et al. 2017). It can be speculated that the overlying clastic marlstone should be the product of gravity flows and the traces were formed after the diagenetic progress of the carbonate stratum.

\section{Discussion}

\subsection{Differences with other similarly-shaped trace fossils}

Petroxestes shows a round bottom in both longitudinal and transverse sections, which is obviously different from other trace fossils. Ignoring this feature, trace fossils with similar morphology include Asthenopodichnium, Teredolites, Rogerella, and Cubiculum.

\subsubsection{Asthenopodichnium}

Asthenopodichnium are small, U-shaped spreiten or pouch-like structures in wooden, organic-rich or bone substrates (Uchman et al. 2007). Traditionally, four ichnospecies have been described, from different substrates: A. xylobiontum (Thenius and Klaus 1979) and A. lignorum (Genise et al. 2012) occur on wood; A. ossibiontum (Thenius 1988) occurs on bone (which has been reinterpreted by Höpner and Bertling 2017, as belonging to a different ichnogenus: Osteichnus ossibiontum); whereas $A$. lithuanicum (Uchman et al. 2007) occurs on the surface of coal seams (Francischini et al. 2016) (Table 1). A. lithuanicum and $A$. ossibiontum are randomly arranged, as are the traces described in this paper, while all reported $A$. xylobiontum and $A$. lignorum are generally arranged with their long axis parallel to the wood fiber. A. lithuanicum is obviously different from Petroxestes from the Yixian Formation by its smaller size (length: 4-7.5 mm) and J-shaped outline. Morphologically, A. ossibiontum is most similar to
Petroxestes, nevertheless, they have only been discovered on fossil bones from Austria (Thenius 1988).

Francischini et al. (2016) reported a new species of Asthenopodichnium, A. fallax, that occurs on clasts of calcrete from the Upper Cretaceous Marília Formation of Brazil. Apart from the smooth and nearly-straight outline in longitudinal section, they are different from Petroxestes in having a higher width/length ratio (0.29).

\subsubsection{Teredolites}

Teredolites are characterized by their single aperture with a more-or-less circular cross-section, their hemispherical distal termination and thin calcite linings (Plint and Pickerill 1985) (Table 1). They have been discovered from nonmarine (e.g., Arua 1991; Plint and Pickerill 1985), marginal or shallow marine (e.g., Chamberlain 1976; Crampton 1990; Dewey and Keady 1987; Dott Jr. and Bourgeois 1982; Francis 1986; Howard and Frey 1984; Kiteley and Field 1984; Lindqvist 1986), and quiet deep marine deposits (e.g., Andersen 1983; Frey 1972; Turner 1973; Wolff 1979). Two different ichnospecies usually occur, a shorter or clavate form, $T$. clavatus Leymerie 1842, and an elongate form $T$. longissimus Kelly and Bromley 1984 (Monaco et al. 2011).

The long axis of $T$. clavatus is usually perpendicular to the substrate (Kelly and Bromley 1984), which is different from Petroxestes from the Yixian Formation. Additionally, its nearly-circular cross-section and hemispherical distal termination make it more distinctive. $T$. longissimus is primarily parallel (e.g., Monaco et al. 2011; Plint and Pickerill 1985; Savrda et al. 1993) or perpendicular (e.g., Arua 1991; Pickerill et al. 2003) to the grain of the substrate. It differs from Petroxestes in size (length greater than $20 \mathrm{~mm}$ ), shapes (tortuous, circular cross-section), arrangement mode (close and parallel with each other), and substrate types (generally in xylic substrates), though having a similar width/ length ratio.

Table 1 Comparison of main features of Petroxestes from the Yixian Formation with other similarly-shaped trace fossils

\begin{tabular}{|c|c|c|c|c|c|c|c|c|c|c|c|}
\hline Ichnogenus & \multirow{2}{*}{ Petroxestes } & \multicolumn{4}{|c|}{ Asthenopodichnium } & \multicolumn{2}{|c|}{ Teredolites } & \multirow{2}{*}{ Rogerella } & \multicolumn{3}{|c|}{ Cubiculum } \\
\hline Ichnospecies & & A. lignorum & A. ossibiontum & A.xylobiontum & A. lithuanicum & T. clavatus & T. longissimus & & C. ornatus & C. inornatus & C. levis \\
\hline Length (mm) & $9-21$ & $15-18$ & $10-15$ & $8-12$ & $4-7.5$ & $6-7$ & $20-130$ & $1.2-2.5$ & $7-20$ & $12-47.6$ & \\
\hline Width (mm) & $1-4$ & $5-6$ & $3-5$ & $2.5-3$ & $1.5-4.5$ & $2-6$ & $2-12$ & $0.2-0.42$ & $2-6$ & $4.9-9.6$ & Bowl shape \\
\hline W/L & $0.1-0.25$ & $0.3-0.4$ & $0.2-0.5$ & $0.2-0.4$ & $0.2-1.1$ & $>0.2$ & $<0.2$ & $0.1-0.2$ & $0.2-0.3$ & $0.2-0.5$ & \\
\hline Substrate & Carbonate rock & Wood & Bone & Wood & Coal & \multicolumn{2}{|c|}{ Wood and lignite } & $\begin{array}{c}\text { Rock, fossil sponge, } \\
\text { echinoidea, } \\
\text { and so on }\end{array}$ & $\begin{array}{l}\text { Compact } \\
\text { spongy bones }\end{array}$ & \multicolumn{2}{|c|}{ Fossil dinosaur bone } \\
\hline Arrange mode & $\begin{array}{l}\text { Randomly } \\
\text { arraned }\end{array}$ & $\begin{array}{l}\text { Parallel to } \\
\text { wood fiber }\end{array}$ & $\begin{array}{c}\text { Randomly } \\
\text { arranged }\end{array}$ & $\begin{array}{l}\text { Parallel to wood } \\
\text { fiber }\end{array}$ & $\begin{array}{c}\text { Randomly } \\
\text { arranged }\end{array}$ & $\begin{array}{c}\text { Generally } \\
\text { perpendicular to } \\
\text { wood fiber }\end{array}$ & $\begin{array}{l}\text { Roughly parallel or } \\
\text { perpendicular to } \\
\text { wood fiber }\end{array}$ & Randomly arranged & $\begin{array}{l}\text { Subparallel to } \\
\text { each other }\end{array}$ & $\begin{array}{c}\text { Singly } \\
\text { preserved }\end{array}$ & $\begin{array}{c}\text { Singly or } \\
\text { gregariously } \\
\text { preserved }\end{array}$ \\
\hline Monomer form & & & & & & & & & & & \\
\hline $\begin{array}{l}\text { Aggregative } \\
\text { form }\end{array}$ & & (2) & & & & & & & & & \\
\hline
\end{tabular}




\subsubsection{Rogerella}

Rogerella (Saint-Seine 1951) presents holes with an elliptical contour and an elongate distal portion, as well as, sometimes, a slight curvature and a circular or conical proximal portion (Brezina et al. 2017) (Table 1). The traces can be found alone or in groups. When grouped, these holes are arranged randomly (e.g., Baird et al. 1990; Brezina et al. 2017) or parallel with each other (e.g., Seilacher 1968, 1969; Donovan and Jagt 2013; Donovan et al. 2016), and in a roughly equidistant, perpendicular or oblique to the substrate surface. They have been discovered on various types of substrates from Devonian to Holocene marine environments (Taylor and Wilson 2003), including carbonate hardgrounds (Brezina et al. 2017), echinoid skeletons (Saint-Seine 1951; Donovan and Jagt 2013; Donovan et al. 2016), belemnite rostra (Seilacher 1968, 1969), gastropods shells (Baird et al. 1990), and so on. Rogerella is most similar in shape to Petroxestes, but significantly smaller (length: $1.2-2.5 \mathrm{~mm}$, and diameter: $0.2-0.42 \mathrm{~mm}$ ).

\subsubsection{Cubiculum}

Cubiculum are regarded as traces of necrophagous or osteophagous insects (Ibrahim et al. 2014). Three species of Cubiculum have been reported, i.e., C. ornatus (Roberts et al. 2007), C. inornatus (Xing et al. 2016) and C. levis (Pirrone et al. 2014). In appearance, C. levis are bowl-shaped, while $C$. ornatus and $C$. inornatus are club-shaped (Table 1). The main difference between $C$. ornatus and $C$. inornatus is that the medial wall of the former has shallow grooves ornamentation, whereas the latter does not. Additionally, C. inornatus were discovered singly, while $C$. ornatus were observed more commonly in dense numbers. Except for morphology, the main difference between Cubiculum and Petroxestes is that the former is only found from fossil biogenic bones.

According to the summation above, it can be seen that traces from the Yixian Formation, in morphology, size, arrange mode and substrate types, are distinguished from Asthenopodichnium, Teredolites, Rogerella, Cubiculum, and other trace fossils. They are more in line with the definition of Petroxestes.

\subsection{Contrast of reported Petroxestes}

Since the first reported Petroxestes from the USA (Wilson and Palmer 1988), they have been found from the Lower Silurian Jupiter Formation from Canada (Tapanila 2001; Tapanila and Copper 2002), the Upper Cretaceous Maastricht Formation from Belgium (Jagt et al. 2009) and the Middle Miocene Grand Bay Formation from Lesser Antilles (Pickerill et al. 2001) (Table 2). Petroxestes from the USA were gregariously distributed in carbonate lithic substrates. The length and width of these traces vary little, while the depth varies greatly. About 20 specimens of Petroxestes were found from the surface of fossils stromatoporoid skeletons in Canada (Tapanila 2001). Except for a larger size, they were morphologically similar with the ones from the USA. There is only one sample from both Belgium and Lesser Antilles, which were produced in a hemipneustid echinoid and a valve of Ostrea, respectively. The Belgium sample has a quite high width/ length ratio, and the Lesser Antilles fossil is much smaller in size than others. Petroxestes fossils from the Yixian Formation are very similar with those from the USA in appearance, arranged mode, distribution density and substrate types (Table 2). The main difference of these traces is that Petroxestes from China have a slightly smaller size. All reported Petroxestes fossils were from marine environments, thus, the samples from China were the first report from a terrestrial environment, which broadened their palaeoenvironmental range.

\subsection{Producer analysis}

Pojeta and Palmer (1976) were of the opinion that a facultative rock-boring modiomorphid bivalve, Corallidomus scobina, produced such traces, based on the presence of a specimen preserved in situ with the borings. Except for this documentation, there are no builder fossils in all the other reported Petroxestes borings. However, it is very clear that Corallidomus scobina are definitely not the builders of all the Petroxestes, because of the large span in geological time (from Late Ordovician to Middle Miocene) and palaeoenvironment types (from marine to terrestrial environments) of these trace fossils.

In ichnology, it is only under exceptional circumstances that the producer of an ichnotaxon can be identified with confidence, because unrelated groups are sometimes morphologically very similar and can therefore produce similar traces, or groups are morphologically very different but behave in a similar manner due to physical or biological parameters and again produce similar traces (Plint and Pickerill 1985; Seilacher 1960). Hence, only potential builders of Petroxestes from the Yixian Formation could be speculated.

There are only 13 species belonging to seven genera of bivalves in the Jehol Group (Jiang and Sha 2007). Only three species belonging to two genera were discovered in the Yixian Formation. They are Arguniella yanshanensis (Gu et al. 1976), A. lingyuanensis (Gu et al. 1976) and Sphaerium anderssoni (Grabau 1923). Sphaerium must have the ability to burrow, crawl and short-distance jump. Arguniella are able to crawl or swim, possibly to burrow, based on their physiological structure characteristics (Private communication with Prof. Sha. in 2017). The substrate was still plastic because some of the burrows were slightly compactionally deformed, which reduced the difficulty of burrowing. The length and height of their fossil records are as follows: A. yanshanensis, 15-21 mm 


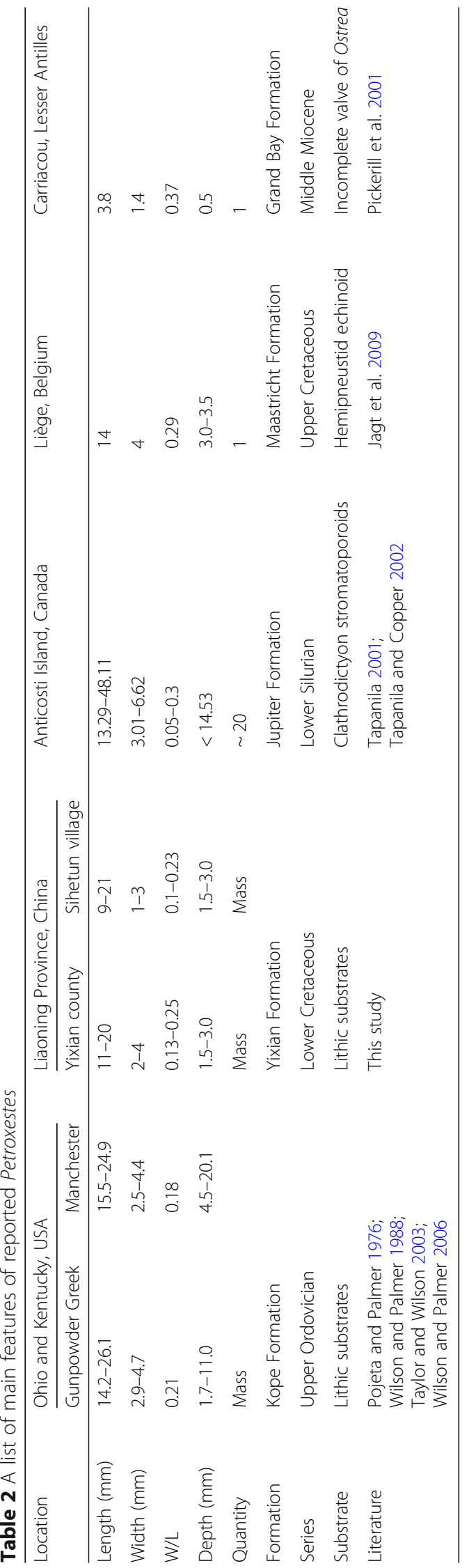


and $10-15 \mathrm{~mm}$; A. lingyuanensis, $8-17 \mathrm{~mm}$ and $4-12 \mathrm{~mm}$; Sphaerium anderssoni, 8-12 $\mathrm{mm}$ and 5-9 $\mathrm{mm}$ (Jiang and Sha 2007). The two former species are more likely to be the builders for their suitable size for these traces. However, it does not rule out the possibilities of other organisms to produce these traces.

\section{Conclusions}

1) Petroxestes have been discovered from the Lower Cretaceous Yixian Formation of western Liaoning, China. This is the first report of Petroxestes from China; meanwhile it is the first report of Petroxestes from a terrestrial environment.

2) Petroxestes from China are very similar with the ones from the USA in appearance, size, arranged mode, distribution density and substrate types, but are different from Asthenopodichnium, Teredolites, Rogerella, Cubiculum and other trace fossils.

3) Petroxestes fossils cannot be produced by the same fabricator, because the large span in geological time and paleoenvironment types of these trace fossils. Petroxestes from the Yixian Formation may be built by some bivalves of Arguniella yanshanensis,

A. lingyuanensis and Sphaerium anderssoni, or other organisms.

\section{Acknowledgements}

This study was supported by the National Natural Science Foundation of China (Grant No. 41172003 and 41572004). The authors thanks Prof. Jin-Geng Sha for his generous share of research works of the ability to dig holes in bivalves.

\section{Authors' contributions}

All authors read and approved the final manuscript.

\section{Competing interests}

The authors declare that they have no competing interests.

\section{Publisher's Note}

Springer Nature remains neutral with regard to jurisdictional claims in published maps and institutional affiliations.

Received: 6 July 2017 Accepted: 13 October 2017

Published online: 13 September 2018

\section{References}

Andersen, Jordan L. 1983. Teredoes: The ubiquitous predator. Oceans 16: 19.

Arua, I. 1991. The trace fossil Teredolites Iongissimus in calcareous concretions from the Eocene Ameki formation, southeastern Nigeria. Journal of African Earth Sciences (and the Middle East) 12 (4):605-608.

Baird, Gordon C., Carlton E. Brett, and Jack T. Tomlinson. 1990. Host-specific acrothoracid barnacles on middle Devonian platyceratid gastropods. Historical Biology 4 (3-4):221-244.

Barrell, Joseph. 1917. Rhythms and the measurements of geologic time. GSA Bulletin 28 (1):745-904.

Brezina, Soledad S., M. Virginia Romero, and Silvio Casadío. 2017. Encrusting and boring barnacles through the cretaceous/Paleogene boundary in northern Patagonia (Argentina). Ameghiniana 54 (1):107-123.

Chamberlain, C.K. 1976. Field guide to the trace fossils of the Cretaceous Dakota Hogback along Alameda Avenue, west of Denver, Colorado. In Seminar on Trace Fossils, ed. C.K. Chamberlain and R.W. Frey, 242-250. Golden, Colorado: Colorado School of Mines.
Chang, Mee-Mann, Pei-Ji Chen, Yuan Wang, and Yuan-Qing Wang. 2003. The Jehol fossils: The emergence of featured dinosaurs, beaked birds and flowering plants. Shanghai: Shanghai Scientific and Technical Publishers.

Chen, Deng-Hui, En-Pu Gong, Jun-Hong Liang, and Xiao-Hong Chen. 2011. The carbon and oxygen stable isotopic compositions and sedimentary environment of the lacustrine carbonate from the upper cretaceous Yixian formation, western Liaoning, NE China. Acta Geologica Sinica 85 (6):987-992 (in Chinese with English abstract).

Chen, Deng-Hui, En-Pu Gong, Jun-Hong Liang, and Yong-Jie Li. 2009. The lacustrine carbonates and their sedimentary environment of lower cretaceous Yixian formation in western Liaoning. Geological Review 55 (6):897-904 (in Chinese with English abstract).

Chen, Deng-Hui, En-Pu Gong, Jun-Hong Liang, Yong-Jie Li, and Xu-Ming Dong. 2010. Mechanism of the chert formation within the lacustrine carbonates of the lower cretaceous Yixian formation, western Liaoning. Acta Geologica Sinica 84 (8):1208-1214 (in Chinese with English abstract).

Chen, Pei-Ji, Zhi-Ming Dong, and Shuo-Nan Zhen. 1998. An exceptionally well-preserved theropod dinosaur from the Yixian formation of China. Nature 391 (6663):147-152.

Crampton, J.S. 1990. A new species of late cretaceous wood-boring bivalve from New Zealand. Palaeontology 33 (4):981-992.

Dewey, C.P., and D.M. Keady. 1987. An allochthonous preserved woodground in the upper cretaceous Eutaw formation in Mississippi. Southeastern Geology 27:165-170.

Ding, Qiuhong, Ning Tian, Yongdong Wang, Zikun Jiang, Shuwang Chen Dong Wang, Wu Zhang, Shaolin Zheng, Aowei Xie, Guogiang Zhang, and Zhongjian Liu. 2016. Fossil coniferous wood from the early cretaceous Jehol biota in western Liaoning, NE China: New material and palaeoclimate implications. Cretaceous Research 61:57-70.

Ding, Qiu-Hong, Li-Dong Zhang, Sheng-Zhe Guo, Chang-Jie Zhang, Yan-Dong Peng, Bin Jia, Shu-Wang Chen, and De-He Xing. 2003. Study on the paleoecology of Yixian formation in Beipiao area, western Liaoning Province, China. Geology and Resources 12 (1):9-18 (in Chinese with English abstract).

Donovan, Stephen K., and John W.M. Jagt. 2013. Rogerella isp. Infesting the pore pairs of Hemipneustes striatoradiatus (Leske) (Echinoidea: Upper cretaceous, Belgium). Ichnos 20 (4):153-156.

Donovan, Stephen K., John W.M. Jagt, and Eric Nieuwenhuis. 2016. Site selectivity of the boring Rogerella isp. Infesting Cardiaster granulosus (Goldfuss) (Echinoidea) in the type Maastrichtian (upper cretaceous, Belgium). Geological Journal 51 (5):789-793.

Dott, R.H., Jr., and Joanne Bourgeois. 1982. Hummocky stratification: Significance of its variable bedding sequences. GSA Bulletin 93 (8):663-680.

Francis, J.E. 1986. Growth rings in cretaceous and tertiary wood from Antarctica and their palaeoclimatic implications. Palaeontology 29:665-684

Francischini, Heitor, Voltaire D. Paes Neto, Agustín G. Martinelli, Vitor P. Pereira, Thiago S. Marinho, Vicente P.A. Teixeira, Mara L.F. Ferraz, Marina B. Soares, and Cesar L. Schultz. 2016. Invertebrate traces in pseudo-coprolites from the upper cretaceous Marília formation (Bauru group), Minas Gerais state, Brazil. Cretaceous Research 57:29-39.

Frey, R.W. 1972. Paleoecology and depositional environment of Fort Hays Limestone Member. Niobrara Chalk (Upper Cretaceous west-central Kansas: The University of Kansas Paleontological Contributions Article 58, Cretaceous 3.

Genise, Jorge F., Romain Garrouste, Patricia Nel, Philippe Grandcolas, Pierre Maurizot, Dominique Cluzel, Rapha L. Cornette, Anne-Claire Fabre, and André Nel. 2012. Asthenopodichnium in fossil wood: Different trace makers as indicators of different terrestrial palaeoenvironments. Palaeogeography, Palaeoclimatology, Palaeoecology 365-366:184-191.

Gong, En-Pu, Deng-Hui Chen, Jun-Hong Liang, and Yong-Li Zhang. 2011 Carbonate interlayers of the Yixian formation in western Liaoning and their environmental significance. Acta Geologica Sinica 85 (4):459-466 (in Chinese with English abstract).

Gong, En-Pu, Jun-Hong Liang, Xiao-Dong Li, Chun-Hong Wang, and Xian-De Cui. 2007. Comprehensive research on the sedimentary environment and palaeogeography of early cretaceous Jehol biota in western Liaoning, China. Acta Geologica Sinica 81 (1):1-8 (in Chinese with English abstract).

Gong, En-Pu, Jiang Xu, Tie-Hui Wang, Yue Liang, and Fei Gao. 2017. Microbialcaddisfly bioherms in the early cretaceous Yixian formation in the Yixian Basin, western Liaoning, China. Cretaceous Research 78:127-138.

Grabau, A.W. 1923. Cretaceous Mollusca from North China. Bulletin of the Geological Survey of China 5 (2):183-198. 
Gu, Z.W., B.Y. Huang, C.Z. Chen, S.X. Wen, et al. 1976. Lamellibranchs of China. Beijing: Science Press (in Chinese).

Guo, Sheng-Zhe, Li-Dong Zhang, Chang-Jie Zhang, Yan-Dong Peng, Bin Jia, Shu-Wang Chen, De-He Xing, Qiu-Hong Ding, and Yue-Juan Zheng. 2001. The progress on the studies of the Yixian formation in western Liaoning Province. Chinese Geology 28 (8): 1-8 (in Chinese with English abstract).

Höpner, Sara, and Markus Bertling. 2017. Holes in bones: Ichnotaxonomy of bone borings. Ichnos 24 (4):259-282.

Hou, Lian-Hai, Zhong-He Zhou, Larry D. Martin, and Alan Feduccia. 1995. A beaked bird from the Jurassic of China. Nature 377 (6550): 616-618.

Howard, James D., and Robert W. Frey. 1984. Characteristic trace fossils in nearshore to offshore sequences, upper cretaceous of east-Central Utah. Canadian Journal of Earth Sciences 21 (2):200-219.

Hu, Y., Y. Wang, Z. Luo, and C. Li. 1997. A new symmetrodont mammal from China and its implications for mammalian evolution. Nature 390 (6656): 137-142.

Huang, Di-Ying. 2015. Yanliao biota and Yanshan movement. Acta Palaeontologica Sinica 54 (4):501-546 (in Chinese with English abstract).

Ibrahim, N., D.J. Varricchio, P.C. Sereno, J.A. Wilson, D.B. Dutheil, D.M. Martill, L. Baidder, and S. Zouhri. 2014. Dinosaur footprints and other ichnofauna from the cretaceous Kem Kem beds of Morocco. PLoS One 9 (6): e90751.

Jagt, John W.M., Christian Neumann, and Stephen K. Donovan. 2009. Petroxestes altera, a new bioerosional trace fossil from the upper Maastrichtian (cretaceous) of Northeast Belgium. Bulletin de l'Institut Royal des Sciences Naturelles de Belgique, Sciences de la Terre 79:137-145.

Ji, Qiang. 2004. Mesozoic Jehol biota of western Liaoning, China. Beijing: Geological Publishing House (in Chinese).

Ji, Qiang, Philip J. Currie, Mark A. Norell, and Shu-An Ji. 1998. Two feathered dinosaurs from northeastern China. Nature 393 (6687):753-761.

Ji, Qiang, and Shu-An Ji. 1996. Discovery of the earliest bird fossil in China and the origin of birds. Chinese Geology 233 (10):30-33 (in Chinese).

Jiang, Bao-Yu, and Jin-Geng Sha. 2007. Preliminary analysis of the depositional environments of the lower cretaceous Yixian formation in the Sihetun area, western Liaoning, China. Cretaceous Research 28 (2):183-193.

Jiang, Bao-Yu, Jin-Geng Sha, and Hua-Wei Cai. 2007. Early cretaceous nonmarine bivalve assemblages from the Jehol group in western Liaoning, Northeast China. Cretaceous Research 28 (2):199-214.

Kelly, Simon R.A., and Richard G. Bromley. 1984. Ichnological nomenclature of clavate borings. Palaeontology 27 (4):793-807.

Kiteley, Louise W. and Michael E. Field. 1984. Shallow marine depositional environments in the upper cretaceous of northern Colorado. In Siliciclastic Shelf Sediments, ed. R.W. Tillman and C.T. Siemers. SEPM Special Publications 34 179-204

Leymerie, A. 1842. Suite de mémoire sur le terrain Crétacé du département de l'Aube. Geological Society of France. Memoir 4:1-34.

Lindqvist, Jon K. 1986. Teredinid-bored Araucariaceae logs preserved in shoreface sediments, Wangaloa formation (Paleocene), Otago, New Zealand. New Zealand Journal of Geology and Geophysics 29 (2):253-261.

Mcllroy, Duncan. 2004. The application of ichnology to palaeoenvironmental and stratigraphic analysis:Introduction. Geological Society, London, Special Publications 228:1-2.

Miller, William. 2007. Trace fossils:Concepts, problems, prospects. Amsterdam: Elsevier.

Monaco, Paolo, Federico Famiani, Roberto Bizzarri, and Angela Baldanza. 2011. First documentation of wood borings (Teredolites and insect larvae) in early Pleistocene lower shoreface storm deposits (Orvieto area central Italy). Bollettino Della Societa Paleontologica Italiana 50 (1):55-63.

Pan, Yan-Hong, Jin-Geng Sha, and Xiao-Gang Yao. 2012. Taphonomy of early cretaceous freshwater bivalve concentrations from the Sihetun area, western Liaoning, NE China. Cretaceous Research 34:94-106.

Pan, Yan-Hong, Jin-Geng Sha, Zhong-He Zhou, and Franz T. Fürsich. 2013. The Jehol biota:Definition and distribution of exceptionally preserved relicts of a continental early cretaceous ecosystem. Cretaceous Research 44:30-38.

Pickerill, R.K., S.K. Donovan, and R.W. Portell. 2001. The bioerosional ichnofossil Petroxestes pera Wilson and Palmer from the middle Miocene of Carriacou. Caribbean Journal of Science 37 (1):130-131

Pickerill, R.K., S.K. Donovan, and R.W. Portell. 2003. Teredolites longissimus Kelly \& Bromley from the Miocene Grand Bay formation of Carriacou, the Grenadines, Lesser Antilles. Scripta Geologica 125 (1):1-9.

Pirrone, Cecilia A., Luis A. Buatois, and Bernardo González Riga. 2014. A new ichnospecies of Cubiculum from upper cretaceous dinosaur bones in western Argentina. Ichnos 21 (4):251-260.
Plint, A. Guy, and Ron K. Pickerill. 1985. Non-marine Teredolites from the middle Eocene of southern England. Lethaia 18 (4):341-347.

Pojeta, John, and T.J. Palmer. 1976. The origin of rock boring in mytilacean pelecypods. Alcheringa:An Australasian Journal of Palaeontology 1 (2):167-179.

Roberts, Eric M., Raymond R. Rogers, and Brady Z. Foreman. 2007. Continental insect borings in dinosaur bone:Examples from the late cretaceous of Madagascar and Utah. Journal of Paleontology 81 (1):201-208.

Saint-Seine, R. 1951. Un Cirripède acrothoracique du Crétacé:Rogerella lecointrei, n. g., n. sp., Académie des Sciences (Paris). comptes rendus 233:1015-1053 (in French).

Savrda, Charles E., Kate Ozalas, Timothy H. Demko, Richard A. Huchison, and Thomas D. Scheiwe. 1993. Log-grounds and the ichnofossil Teredolites in transgressive deposits of the Clayton formation (lower Paleocene), western Alabama. Palaios 8 (4):311-324.

Seilacher, Adolf. 1960. Lebensspuren als Leitfossilien. Geologische Rundschau 49 (1):41-50 (in German).

Seilacher, Adolf. 1968. Swimming habits of belemnites - Recorded by boring barnacles. Palaeogeography, Palaeoclimatology, Palaeoecology 4 (4) 279-285.

Seilacher, Adolf. 1969. Paleoecology of boring barnacles. American Zoologist 9 (3): 705-719.

Sha, Jin-Geng. 2007. Cretaceous stratigraphy of Northeast China:Non-marine and marine correlation. Cretaceous Research 28 (2):146-170.

Sun, Ge, David L. Dilcher, Shao-Ling Zheng, and Zhe-Kun Zhou. 1998. In search of the first flower:A Jurassic angiosperm, Archaefructus, from Northeast China. Science 282 (5394):1692-1695.

Tapanila, L. 2001. "Bioerosion in Late Ordovician and Early Silurian Tropical Carbonate Settings of Anticosti Island, Québec, Canada. [Doctoral Thesis]" School of Graduate Studies, Laurentian university, Sudbury Canada, 19-21.

Tapanila, L., and P. Copper. 2002. Endolithic trace fossils in Ordovician-Silurian corals and stromatoporoids, Anticosti Island, eastern Canada. Acta Geológica Hispánica 37 (1):15-20.

Taylor, P.D., and M.A. Wilson. 2003. Palaeoecology and evolution of marine hard substrate communities. Earth-Science Reviews 62 (1-2):1-103.

Thenius, E. 1988. Lebensspuren von aquatischen Insektenlarven aus dem Jungtertiar Niederosterreichs. [trace fossils from nymphs of aquatic insects from the Neogene of Lower Austria]. Beiträge für Palaeontogie Oesterreich 14:1-18 (in German).

Thenius, Erich, and Wilhelm Klaus. 1979. Lebensspuren von EphemeropterenLarven aus dem Jung-Tertiär des Wiener Beckens. Annalen Des Naturhistorischen Museums in Wien 82:177-188 (in German).

Turner, R.D. 1973. Wood-boring bivalves, opportunistic species in the deep sea. Science 180 (4093):1377-1379.

Uchman, Alfred, Gaigalas Algirdas, M. Melešyte, and Vaidotas Kazakauskas. 2007. The trace fossil Asthenopodichnium lithuanicum isp. Nov. from late Neogene brown-coal deposits, Lithuania. Geological Quarterly 51 (3):329-336.

Wang, Wu-Li, Hong Zhang, Li-Jun Zhang, Shao-Lin Zheng, Fang-Lin Yang, ZhiTong Li, Yue-Juan Zheng, and Qiu-Hong Ding. 2004. Standard stratigraphic sections of Tuchengzi stage and Yixian stage and their Stratigraphical Palaeontology and tectonic-volcanic activities, 92-110. Beijing:Geological Publishing House (in Chinese).

Wang, Xiao-Lin, Yuan-Qing Wang, Yuan Wang, Xing Xu, Zhi-Lu Tang, Fu-Cheng Zhang, Yao-Ming Hu, Gu Gang, and Zhao-Lin Hao. 1998. Stratigraphic sequence and vertebrate-bearing beds of the lower part of the Yixian formation in Sihetun and neighbouring area, western Liaoning, China. Vertebrata Palasiatica 36 (2):81-101 (in Chinese with English summary).

Wilson, Mark A., and Timothy J. Palmer. 1988. Nomenclature of a bivalve boring from the upper Ordovician of the midwestern United States. Journal of Paleontology 62 (2):306-308.

Wilson, Mark A., and Timothy J. Palmer. 2006. Patterns and processes in the Ordovician bioerosion revolution. Ichnos 13 (3):109-112.

Wolff, Torben. 1979. Macrofaunal utilization of plant remains in the deep sea. Sarsia $64(1-2): 117-143$.

Xing, Li-Da, Jerald D. Harris, Xiang-Yang Feng, and Zhi-Jun Zhang. 2009 . Theropod (Dinosauria:Saurischia) tracks from lower cretaceous Yixian formation at Sihetun Village, Liaoning Province, China and possible track makers. Geological Bulletin of China 28 (6):705-712.

Xing, Li-Da, Alexander H. Parkinson, Hao Ran, Cecilia A. Pirrone, Eric M. Roberts, Jian-Ping Zhang, Michael E. Burns, Tao Wang, and Jonah Choiniere. 2016. The earliest fossil evidence of bone boring by terrestrial invertebrates, examples from China and South Africa. Historical Biology 28 (8):1108-1117. 
Zhang, Xiao-Lin, Gui-Jie Zhang, and Jin-Geng Sha. 2016. Lacustrine sedimentary record of early Aptian carbon cycle perturbation in western Liaoning, China. Cretaceous Research 62:122-129.

Zhang, Ya-Nan, En-Pu Gong, and Jun-Hong Liang. 2006. The structural analysis and correlation of sedimentary sections of Yixian formation in western Liaoning Province. Geology and Resources 15 (1):20-24 (in Chinese with English abstract)

Zhu, Guang, Zhao-Qi Hu, Yin Chen, Man-Lan Niu, and Cheng-Long Xie. 2008 Evolution of early cretaceous extensional basins in the eastern North China craton and its implication for the craton destruction. Geological Bulletin of China 27 (10):1594-1604 (in Chinese with English abstract).

\section{Submit your manuscript to a SpringerOpen ${ }^{\circ}$ journal and benefit from:}

- Convenient online submission

- Rigorous peer review

- Open access: articles freely available online

- High visibility within the field

- Retaining the copyright to your article

Submit your next manuscript at $\boldsymbol{\sim}$ springeropen.com 